7 Mikkelsen M, Vestermark S. Karyotype 45,XX,-21/ $46, X X, 21 q-$ in an infant with symptoms of G-deletion syndrome I. J Med Genet 1974 ;11:389-93.

8 Yamamoto Y, Ogasawara N, Gotoh A, Komiya $\mathbf{H}$, Nakai H, Kuroki Y. A case of $21 q-$ syndrome with normal SOD-1 activity. Hum Genet 1979;48:321-7.

- de Grouchy J, Turleau C. Atlas des maladies chromosomiques. 2nd ed. Paris: Expansion Scientifique Française, 1982.

10 McKusick VA. Mendelian inheritance in man. 5th ed. Baltimore: Johns Hopkins University Press, 1979.

11 Alkemade PPH. Dysgenesis mesodermalis of the iris and the cornea. A study of Rieger's syndrome and Peter's anomaly. Assen: Royal Vangorcum, 1969.

12 Abeliovich D, Carmi R, Karplus M, Bar-Ziv J, Cohen MM. Monosomy 21: a possible stepwise evolution of the karyotype. Am J Med Genet 1979;4:279-86.

13 Kaneko Y, Ikeuchi T, Sasaki M, Satake Y, Kuwajima S. A male infant with monosomy 21. Hum Genet 1975;29: $1-7$.

14 Heinemann MH, Breg R, Cotlier E. Rieger's syndrome with pericentric inversion of chromosome $6 . \mathrm{Br} J$ Ophthalmol 1979;63:40-4.
16 Tabbara KF, Khouri FP, DerKaloustian VM. Rieger's syndrome with chromosomal anomaly. Can J Ophthalmol 1973;8:488-91.

16 Reese AB, Ellsworth RM. The anterior chamber cleavage syndrome. Arch Ophthalmol 1966;75:307-18.

17 Huggert A. The trisomy 18 syndrome. A report of three cases in the same family. Acta Ophthalmol 1966;44: 186-95.

18 Ginsberg J, Soukup S, Ballard ET. Pathologic features of the eye in trisomy 9. J Pediatr Ophthalmol 1982;19:37-41.

19 Francois J, Berger R, Saraux H. Les aberrations chromosomiques en ophthalmologie. Paris: Masson et Cie, 1972: 147-65.

20 Ligutić I, Brécevic L, Peikovic I, Kalogjera T, Rajie Z. Interstitial deletion 4q and Rieger syndrome. Clin Genet 1981 ;20:323-7.

Correspondence and requests for reprints to Dr L Tranebjærg, Department of Medical Genetics, The John F Kennedy Institute, Gl Landevej 7, DK 2600 Glostrup, Denmark.

\title{
Inv dup (15) with mental retardation but few dysmorphic features
}

\author{
D H GILMORE, E BOYD, J P MCCLURE*, P BATSTONE, \\ AND J M CONNOR \\ Duncan Guthrie Institute of Medical Genetics, Yorkhill, Glasgow G3 8SJ; and \\ *Ayrshire Central Hospital, Kilwinning Road, Irvine, Scotland.
}

SUMMARY We report a Scottish child with inv dup (15) and compare the clinical features with those of previously reported cases.

Since the first report by Parker and Alfi in 1972,1 there have been 44 reports of patients with confirmed or suspected inv dup (15). The extra chromosomal material has been variously described, but in all cases there appears to be an additional $\mathbf{G}$ group sized chromosome in which both ends are derived from the short arm, centromere, and proximal long arm of chromosome 15. In most cases there are satellites at both ends of this extra chromosome.

We report the first patient from Scotland with similar cytogenetic findings.

\section{Case report}

The proband was referred for assessment of developmental delay. He was the third child of nonconsanguinous Scottish parents. His father was 44 years old and his mother was 30 years old at the time of his birth. The pregnancy was uneventful

Received for publication 19 September 1983.

Accepted for publication 21 October 1983. and spontaneous vertex delivery occurred at term. His birth weight was $3.43 \mathrm{~kg}$.

All developmental milestones were delayed. $\mathrm{He}$ sat unsupported and crawled at the age of 10 months. He walked with support at 22 months. Speech development has also been delayed.

He underwent a right inguinal hernia repair at 12 months but otherwise has had good general health.

At 2.5 years of age examination revealed height, weight, and head circumference all on the 50th centile. His eyes had an antimongoloid slant and he tended to hold his head in dorsiflexion. Interpupillary distance was $4.8 \mathrm{~cm}$ (50th centile) and inner intercanthal distance was $2.6 \mathrm{~cm}$ (50th centile). Dermatoglyphs were abnormal with arches on five fingers. Apart from developmental delay, the remainder of his clinical examination was unremarkable.

\section{CYTOGENETICS}

Chromosome analysis of cultured lymphocytes by Giemsa banding, C banding, and DAPI/Distamycin A staining revealed a $47, \mathrm{XY}$ chromosome constitution, with a small additional chromosome derived 

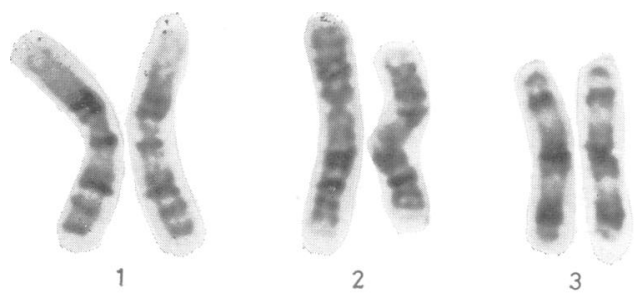

3

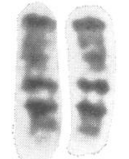

7

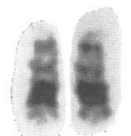

13

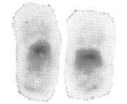

19

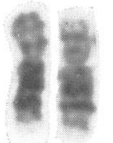

8

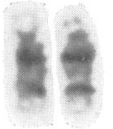

14

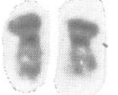

20

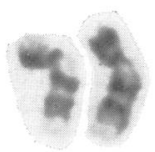

9

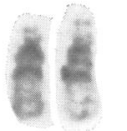

15

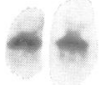

21

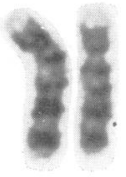

4

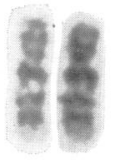

10

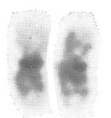

16

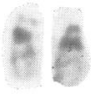

22

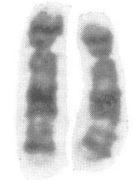

5

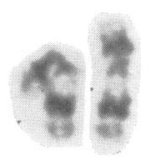

11

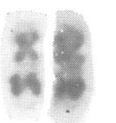

17

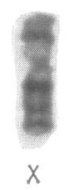

FIGURE Karyotype of proband.

from the short arm, centromere, and proximal region of the long arm to q13 of two number 15 chromosomes. This chromosome was satellited at both ends and was present in all cells examined (figure).

The short arm and satellites at one end were clearly larger than those at the other, and both ends were observed to take part in satellite association. $\mathrm{C}$ banding confirmed that the chromosome was dicentric and suggested that the centromere with the smaller short arm and satellite was inactivated. DAPI/Distamycin A staining indicated that the chromosome included the centromere regions of two number 15 chromosomes.

Parental karyotypes were normal.

\section{Discussion}

Wisniewski et $a l^{2}$ reviewed reports of inv dup (15) up to 1979 . We identified 12 additional suspected cases reported before 1979 and a further six since that time..$^{3-10}$ With the present report there are now 45 reported patients with confirmed or suspected inv dup (15).

In the more recent case reports, the use of anti-5methylcytosine or DAPI/Distamycin A staining has shown the additional chromosome to consist of a duplicated area of chromosome 15 which includes the short arm, centromeric heterochromatin, and proximal long arm. Thus, affected subjects are $\dot{0}$ tetrasomic for loci in these regions of chromosome 15. The breakpoint on the long arm shows some variation but is often at $\mathrm{q} 21 \rightarrow \mathrm{q} 23$.

The clinical features of these patients are sum- 을 marised in the table. Some phenotypic variation $>$ exists but, as in our case, most reports are of children with few or no dysmorphic features. $\bar{N}$ Mental retardation is however universal. Although $\sigma$ some children are only mildly retarded, most have $\mathbb{O}$ been moderately to severely retarded. The degree of N retardation has not correlated with the size of the 0 additional chromosome. Abnormal tone, seizures, 0 and behaviour disturbances are the other common $\stackrel{D}{D}$ features. The sex ratio is 1 male to 0.8 females. $\stackrel{\mathcal{P}}{?}$ Both the birth history and birth weight are un- 0 remarkable. Major congenital malformations are notably absent in these patients.

Of these 45 patients, 29 had chromosomally $\underset{\mathbb{Q}}{\mathbb{Q}}$ normal parents. In six cases there was a familial $\bar{\sigma}$ translocation, in one family the mother was a 
TABLE Clinical features in 45 reported cases of inv dup (15).

\begin{tabular}{ll}
\hline & $\%$ \\
\hline Mental retardation & 98 \\
Developmental delay & 87 \\
Abnormal tone & 58 \\
Seizures & 53 \\
Abnormal ears & 51 \\
Strabismus & 49 \\
Growth retardation & 42 \\
Behaviour disturbance & 37 \\
Abnormal dermatoglyphs & 33 \\
Antimongoloid slant & 31 \\
High arched palate & 29 \\
Abnormal speech & 29 \\
Epicanthus & 20 \\
Abnormal EEG & 11 \\
Facial asymmetry & 7 \\
Anteverted nares & 5 \\
Kyphoscoliosis & 5 \\
\hline
\end{tabular}

mosaic, and in the remainder parental karyotypes were not performed. In the non-inherited group, parental ages were stated in 20 families: for these the average maternal age at birth was 33.4 years and the average paternal age was 37.4 years. All of these de novo cases have been isolated events. The recurrence risk for parents with normal chromosomes thus appears to be low. To date there have been three reports of recurrence, two owing to parental translocation and one to maternal mosaicism. Those cases where a parental translocation was the cause had additional phenotypic features reflecting the partial trisomy or monosomy of the other chromosome involved in the translocation. In these situations amniocentesis is indicated for future pregnancies. $^{2} 8$

The origin of the extra chromosome in the noninherited cases is unknown. Various theories have been postulated. ${ }^{11} \mathrm{~A}$ study of the relative significance of birth order to maternal age and paternal age might help to clarify the likely parental origin in view of the observed increase in mean parental ages.

We wish to thank Action Research for the Crippled Child for their continued support.

References

1 Parker CE, Alfi OS. Partial trisomy of chromosome 15. Lancet $1972 ; \mathrm{i}: 1073$.

2 Wisniewski L, Hassold T, Heffelfinger J, Higgins JV. Cytogenetic and clinical studies in five cases of inv dup (15). Hum Genet 1979;50:259-70.

3 Mankinen CB, Holt JG, Sears JW. Partial trisomy 15 in a young girl. Clin Genet 1976;10:27-32.

4 Taysi K, Devivo DC, Sekhon GS. Partial trisomy 15 and intractable seizures. Acta Paediatr Scand 1979;68:445-7.

5 Bannister DL, Engel E. A G-like trisomy with a major 15 proximal supernumerary component derived from a D/E balanced maternal translocation. J Pediatr 1975;86: 916-8.

6 Howard PN, Stoddard GR, Yarbrough KM. Partial trisomy D and Giemsa banding. Am J Hum Genet 1974; 26:41 A.

7 Furbetta M, Rosi G, Biagioni M, Cossu P, Cao A. A case of extra small acrocentric bisatellited chromosome in a non-mongoloid child. Humangenetik 1975;30:259-63.

8 Breg WR. In: Yunis JJ, ed. New chromosomal syndromes. New York: Academic Press, 1977:322.

9 Zannoti M, Preto A, Giovanardi PR, Dallapicolla B. Extra dicentric pter leads to q21/22 chromosomes in five unrelated patients with a distinct syndrome of progressive psychomotor retardation, seizures, hyper reactivity and dermatoglyphic abnormalities. J Ment Defic Res 1980; $4: 235-42$.

10 Fujita H, Sakamoto Y, Hamamoto Y. An extra idic (15p) (q11) chromosome in Prader-Willi syndrome. Hum Genet 1980;55:409-11.

11 Schreck RR, Breg WR, Erlanger BF, Miller OJ. Preferential derivation of abnormal human G-like chromosomes from chromosome 15. Hum Genet 1977;36:1-12.

Correspondence and requests for reprints to $\mathrm{Dr}$ J M Connor, Department of Medical Genetics, Duncan Guthrie Institute of Medical Genetics, Yorkhill, Glasgow G3 8SJ.

\title{
Interstitial deletion of the short arm of chromosome 4
}

\author{
M RAY, J EVANS, C ROCKMAN-GREENBERG, AND D WICKSTROM \\ Division of Human Genetics, and Department of Pediatrics and Child Health, University of Manitoba \\ and Health Sciences Centre, Winnipeg, Manitoba, Canada.
}

SUMMARY A 17 year old girl investigated for mental retardation and minor anomalies was found to have an interstitial deletion of $4 \mathrm{p}$. Her clinical and cytogenetic findings are compared with previous reported case of interstitial $4 p$ deletion and with terminal $4 \mathrm{p}-$ deletions (WolfHirschhorn syndrome).

Received for publication 5 September 1983. Accepted for publication 3 October 1983.
Before chromosome banding it was not possible to distinguish terminal and interstitial deletions and therefore few interstitial deletions have been reported. We describe a 17 year old girl with an interstitial deletion of segment p12p15 of chromosome 4. Francke et $a l^{1}$ reported a similar patient with a deletion of segment $4 \mathrm{p} 11 \mathrm{p} 15$. These patients show some similarity in clinical features suggesting that a recognisable phenotype may be associated with this deletion. 